\begin{abstract}
"Mircea cel Batran" Naval Academy Scientific Bulletin, Volume XX - 2017 - Issue 1
The journal is indexed in: PROQUEST I DOAJ / Crossref / EBSCOhost / INDEX COPERNICUS / DRJI / OAJI I JOURNAL INDEX I I2OR / SCIENCE LIBRARY INDEX / Google Scholar / Academic Keys/ ROAD Open Access I Academic Resources / Scientific Indexing Services / SCIPIO / JIFACTOR
\end{abstract}

\title{
DYNAMIC POSITIONING. A CASE STUDY
}

\author{
Constantin C. MAFTEI ${ }^{1}$ \\ Sergiu LUPU ${ }^{2}$ \\ ${ }^{1}$ C/O.eng. Ph.D. student, "Mircea cel Batran" Naval Academy, Constanta, Romania cristi.maftei@anmb.ro \\ ${ }^{2}$ Lecturer eng.Ph.D., "Mircea cel Batran" Naval Academy, Constanta, Romania sergiu.lupu@anmb.ro
}

\begin{abstract}
Ship's dynamic positioning (D.P.) it's technology with a fast development, born from a necessity of a precise positioning for offshore vessels inside of oil and gas reserve exploitation industry. In 1961 the ship Eureka was the first ship which was fully accepted as a DP vessel. For keeping the vessel or structure in fix position is few methods which include spread and fixed moorings or combinations of each. The jack-up rig or vessels using moorings or legs may also occasionally have DP control systems to assist the setting-up on position and, in the case of a moored unit, to reduce mooring line tension. Each system has advantages and disadvantages. Every ship it's a subject of wind forces, waves, and tidal movements, as well of propulsion forces and of other external elements. The answer of these forces is the ship movement, produced by changing the position and heading. These are measured by position reference systems and gyrocompasses. DP control system is calculating the compensation between the measured values of position/heading and the setting values and calculates the propulsion force to be generated to reduce the errors to zero. The aim of this paper is to present a case study regarding how it work the dynamic positioning system on board the ship operating in the Black Sea.
\end{abstract}

Key words: dynamic positioning, fix position, external forces

\section{General information}

Ship's dynamic positioning (D.P.) it's technology with a fast development, born from a necessity of a precise positioning for offshore vessels inside of oil and gas reserve exploitation industry,between the 1960 s and 1970 s.

Activities of oil and gas offshore industries lead to imposing of a clear demands and procedures sets to adopt environmental-friendly methods. That why the area of Dynamic Positioning techniques and technology found a great development.

Eureka has been the first ship which was fully accepted as a DP vessel, designed and engineered by Howard Shatto in 1961.

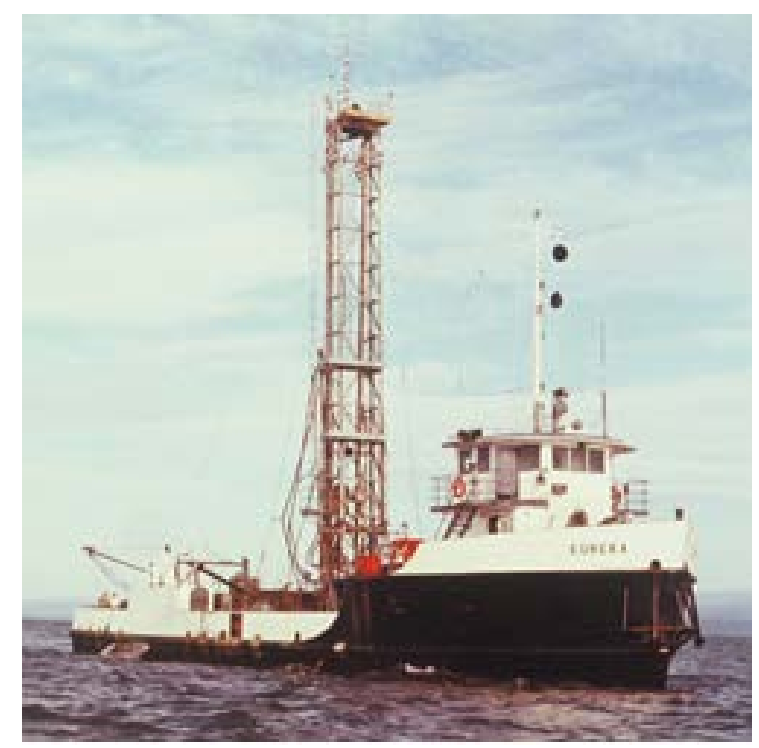

Fig. 1 Eureka first DP vessel
This vessel was equipped with an analog system for controlling the basic movements and interface with a taut wire local reference system.

In addition to main propulsion was fitted with fore and aft steerable thrusters having a displacement of 450 tons and 130 feet in length.

In last 20 years, the diversity and functionality of DP vessels also grow for ships unrelated with offshore industry. Activities executed by DP vessels can be: exploration and exploitation drilling, core sampling, diving support, rigid \& flexible pipe laying, cable lay \& repair, accommodation, hydrographic research \& survey, pre \& post operational survey, wreck inspection (survey, salvage \& removal), subsea installation, well stimulation, platforms supply, storage \& crude oil transport, passenger cruises, mine removing, oceanographic research, technological seabed mining, platform positioning, ship-to-ship transfer and conventional vessel maneuverings.

This DP system became over the years very complicated and sophisticated but meantime more and more reliable. All ships designed for high-risk operations have been fitted with improved position reference systems, and redundant equipment is provided.

\section{Keeping position}

For keeping the vessel or structure in fix, position is few methods which include spread and fixed moorings or combinations of each. The jack-up rig or vessels using moorings or legs may also occasionally have DP control systems to assist the setting-up on position and, in the case of a moored unit, to reduce mooring line tension (Fig. 2). 
"Mircea cel Batran" Naval Academy Scientific Bulletin, Volume XX - 2017 - Issue 1

The journal is indexed in: PROQUEST / DOAJ / Crossref / EBSCOhost / INDEX COPERNICUS / DRJI / OAJI I

JOURNAL INDEX I I2OR / SCIENCE LIBRARY INDEX / Google Scholar / Academic Keys/ ROAD Open Access I Academic Resources / Scientific Indexing Services / SCIPIO / JIFACTOR

Each system has advantages and disadvantages.

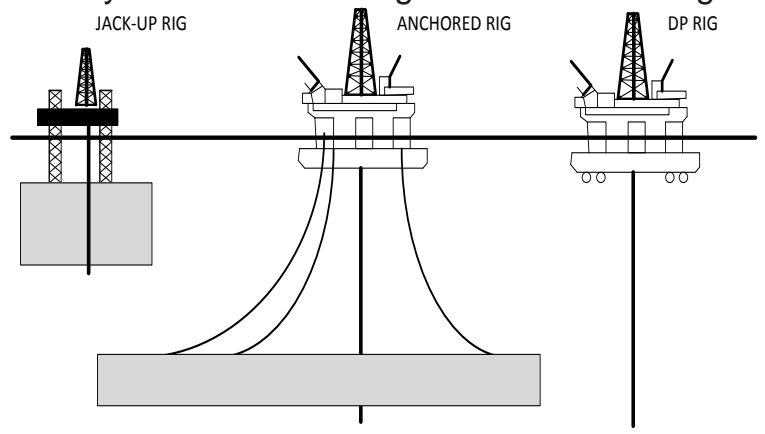

Fig. 2 Methods for fixed position

DP advantages:

- the vessel is fully self-propelled; no tugs are required at any stage of the operation;

- setting up on location is quick and easy;

- the vessel is very maneuverable;

- rapid response to weather changes is possible (weather vane);

- rapid response to changes in the requirements of the operation;

- versatility within a system (i.e. track-follow, ROV-follow and other specialist functions);

- ability to work in any water depth;

- can complete short tasks more quickly, thus more economically;

- avoidance of risk of damaging seabed hardware from mooring lines and anchors;

- avoidance of cross-mooring with other vessels or fixed platforms;

- can move to new location rapidly (also avoid bad weather).

DP disadvantages:

- high capital and operational expenditure;

- can fail to keep position due to equipment failure:

- higher day rates than comparable moored systems;

- higher fuel consumption;

- thrusters are hazards for divers and ROVs;

- can lose position in extreme weather or shallow waters and strong tides;

- position control is active and relies on the human operator (as well as equipment);

- requires more personnel to operate and maintain equipment.

Taking into account the above, it's easy to see that the DP system is not always the most economic solution. However, even the moored vessels have an advantage. Still, the DP system is the most efficient solution for many operations because the sea bed is crowded with pipes and other structures and anchorage in that area have a high risk of damage to pipelines or wellheads.
Mooring at platform legs instead of anchorage is not so reliable option because the support vessels become's bigger and offshore structures are not designed to support the loads that can be placed in mooring lines.

\section{DP system basics}

Dynamic Positioning can be described as an integration of some shipboard systems to obtain the ability of accurate maneuverability. DP can be defined as:

A system which automatically control's a vessel position and heading exclusively using active thrusters.

So, the DP system means keeping the fixed position, precise maneuverability, following the track and other specialist positioning abilities.

Elements of a DP system can be as follows (Fig. 3):

- environment reference systems;

- position reference system;

- heading reference;

- thrusters and propulsion system;

- power generation;

- Dp operator.

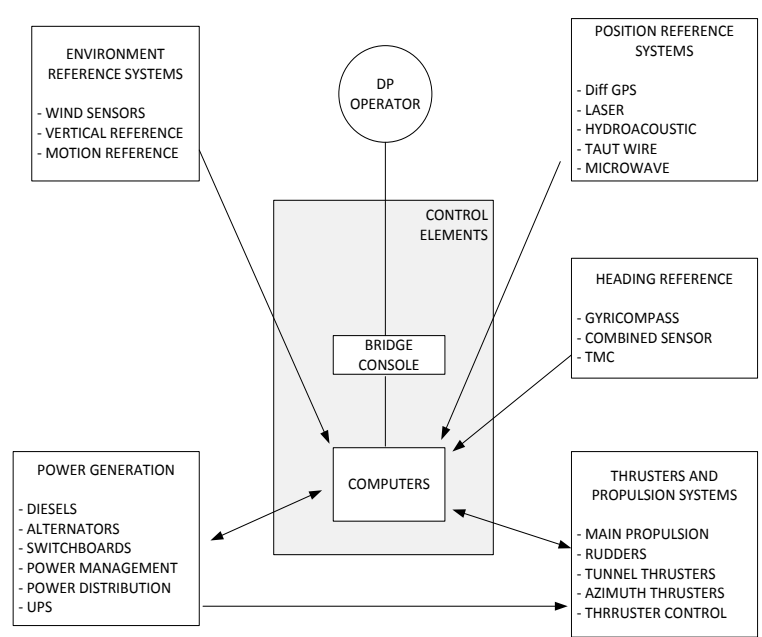

Fig. 3 The elements of DP system

The main designation of DP system is to allow the vessel or floating structure to keep the own position and heading, considering that any vessel (or another object) has six freedoms of movement; three rotations and three translations. In a vessel they can be illustrated as roll, pitch, yaw, surge, sway and heave (Fig. 4). 
"Mircea cel Batran" Naval Academy Scientific Bulletin, Volume XX - 2017 - Issue 1 The journal is indexed in: PROQUEST I DOAJ / Crossref / EBSCOhost / INDEX COPERNICUS / DRJI / OAJI I JOURNAL INDEX I I2OR / SCIENCE LIBRARY INDEX / Google Scholar / Academic Keys/ ROAD Open Access I Academic Resources / Scientific Indexing Services / SCIPIO / JIFACTOR

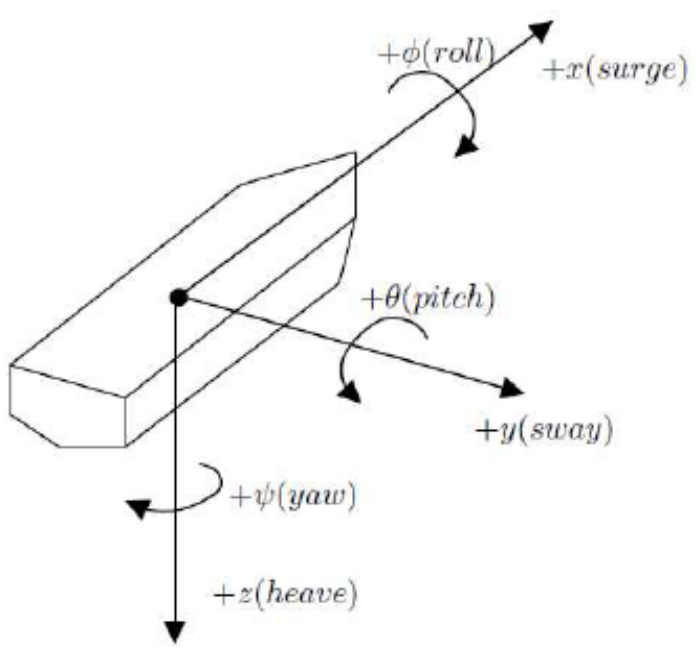

Fig. 4 The 6 DoF ship's motions

Dynamic positioning concerns directly the automatic control of sway, surge, and yaw. Longitudinal and translation movement are strictly related to the vessel position, while yaw is related to vessel orientation (heading). These movements are controlled by the operator who makes the set points for position and heading. Ship position and orientation must be measured to obtain the errors from the settled values. The position is measured by one or more fitted reference systems, and heading information is given by one or more gyrocompasses. The offset or the error is the difference between the setpoint and the feedback, so the DP system is working to cover and minimize these differences.

To keep the position, DP system operates for keep in balance all forces and moments which act against the ship: force in longitudinal movement $(F x)$, force in transversal movement $(F y)$ and rotation moment $(M z)$

$$
\sum F=F_{\text {wind }}+F_{\text {wave }}+F_{\text {current }}+F_{\text {ice }}+F_{\text {control }}=0 \text { (1) }
$$

All forces and moments given by wind, waves and current are applied equally and opposite sense such that the sum will be zero.

Must be kept in mind that each of environmental forces is depending on time and the other variables such as ship heading.

For meeting efficiently this equilibrium and to optimize the fix positioning performance, must understand very well how it's rise these individual environmental forces. Understanding the environmental processes lead to numerical models development and in reply the numerical models become's a part of a control algorithm.

\section{DP operational model}

Every ship it's a subject of wind forces, waves, and tidal movements, as well of propulsion forces and of other external components (fire fighting monitors, tension of pipe/cable laid on sea bed, etc.)
The answer of these forces is the ship movement, produced by changing the position and heading. These are measured by position reference systems and gyrocompasses. DP control system is calculating the compensation between the measured values of position/heading and the setting values and calculates the propulsion force to be generated to reduce the errors to zero. Also the DP, the system calculates the wind acting force and the needed power to counteract, based on a model which is located in control bridge computer (Fig. 5).

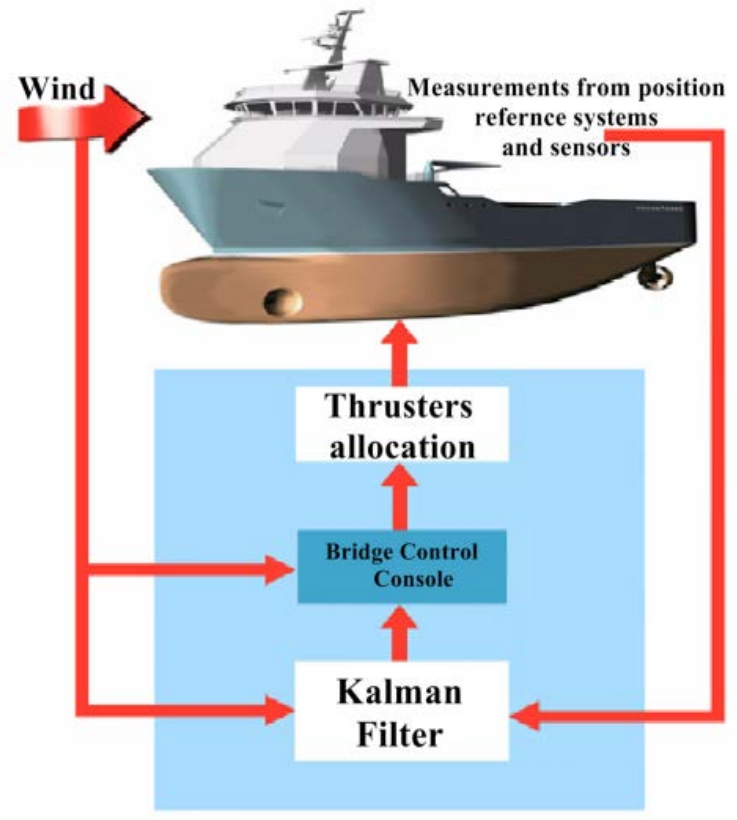

Fig. 5 DP system block diagram [Kongsberg,2006]

The difference between model computed power and wind speed/direction is a force considered as current. Current force or sea force, however, it is, therefore, a sum of all forces and errors from DP model, displayed on a screen as direction and speed of current (Fig, 6).

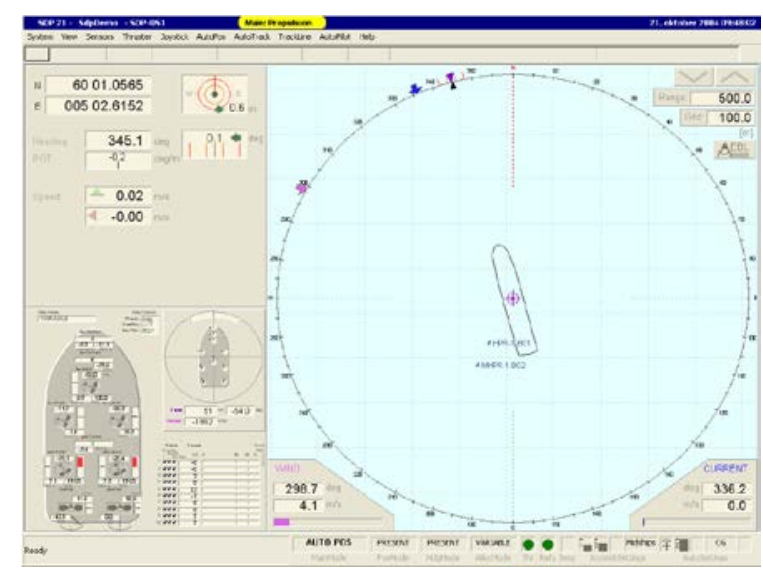

Fig. 6 Control console DP interface using standard menus and dialog boxes 
"Mircea cel Batran" Naval Academy Scientific Bulletin, Volume XX - 2017 - Issue 1 The journal is indexed in: PROQUEST / DOAJ / Crossref / EBSCOhost / INDEX COPERNICUS I DRJI / OAJI I JOURNAL INDEX / I2OR / SCIENCE LIBRARY INDEX / Google Scholar / Academic Keys/ ROAD Open Access I Academic Resources / Scientific Indexing Services / SCIPIO I JIFACTOR

\section{A particular case of a ship DP operating in} West Black Sea area.

To have a close look at a real DP operating situation, we'll take this particular case of a ship

\begin{tabular}{|c|c|c|}
\hline appr & GRT & 2690 \\
\hline oach & NRT & 807 \\
\hline ing & Deadweight & $2020 \mathrm{MT}$ \\
\hline and & Light ship's & 2639MT \\
\hline posit & Keel laid & 04 AUG. 2003 \\
\hline ionin & Launching & 30 NOV. 2004 \\
\hline$g$ & Delivery & 07 MAR. 2005 \\
\hline clos & LOA & $70.00 \mathrm{~m}$ \\
\hline e to & Length water line & $66.80 \mathrm{~m}$ \\
\hline & Breadth(moulded) & $16.80 \mathrm{~m}$ \\
\hline & Depth (molded) & $7.50 \mathrm{~m}$ \\
\hline & Draft(extreme) & $6.11 \mathrm{~m}$ \\
\hline & Speed & 14Knots \\
\hline & Class & American Bureau of Shipping \\
\hline & Notation & ABS+A1(E)Offshore Support,, FI-FI Vessel, Class1+AMS+DPS-2 \\
\hline & Main engine & Wartsila 2X 4000 Kwatts \\
\hline & Generator & $\begin{array}{l}\text { TOW(2)Xcarterpilar3408 DITA c/w Leroy Somer, Alternator LSAM47 } \\
\text { IL } 9 \text { rated } 370 \mathrm{kw} 440 \mathrm{v} / 3 \mathrm{ph} / 60 \mathrm{~Hz}\end{array}$ \\
\hline & Propulsion & Reduction Gearbox-SCV85-P58(5.5:1), CPP Propeller-Wartsila-Lips \\
\hline & $\mathrm{AH}$. wire length/dimension. & $600 \mathrm{~m}-76 \mathrm{~mm} \varnothing \mathrm{Wire}$ \\
\hline & AH.wire spare/leght/dim. & 400m-76mm $\varnothing$ Wire \\
\hline & Bow thruster & $\begin{array}{l}\text { Kawasaki KT-88B3, Propeller Dia:1650mm(Skewed Type)x4blades } \\
\text { Thrust:Approx.10 tones, Motor driven: } 680 \mathrm{kw} / 3 \mathrm{ph} / 60 \mathrm{~Hz}\end{array}$ \\
\hline
\end{tabular}

Table 1. Ship's Characteristics

Beyond the whole clear stated procedures for a DP vessel when is approaching to an offshore structure, we can synthesize a few important setting steps to be made to get the vessel using the DP system in a close operating fixed position.

Before starting the operation and vessel are stopped and switched to Standby mode (is the default mode when the system is first switched on). In this mode, the system is prepared for the operation.

The Dp operator makes the following default settings (Fig. 7):

- enable the sensors (Gyro, Wind, VRS and Speed);

- alarms limits for position and VRS (vertical reference system);

- gain control setting;

- enable the thrusters and rudders;

- enable and calibrate the DGPS. an offshore structure. This vessel is an A.H.T.S. type (Anchor Handling Tug Supply), having a DP Class 2 and the particulars (Tab. 1) 


\begin{abstract}
"Mircea cel Batran" Naval Academy Scientific Bulletin, Volume XX - 2017 - Issue 1 The journal is indexed in: PROQUEST I DOAJ / Crossref / EBSCOhost / INDEX COPERNICUS / DRJI / OAJI I JOURNAL INDEX I I2OR / SCIENCE LIBRARY INDEX / Google Scholar / Academic Keys/ ROAD Open Access I Academic Resources / Scientific Indexing Services / SCIPIO / JIFACTOR
\end{abstract}

The following functions are also available:

- Generator Load Limitation;

- Diesel Engine Load Limitation;

- Diesel Engine Monitoring;

- Thruster Load Monitoring (Current/Power).

After the operating settings are done, system is switched in Joystick mode and after a vessel is stabilized Auto Position mode can be switched on. As it shows in figure 8, it can see the ship's track when moving astern step by step with the desired incremented setpoint (15.4 meters left).

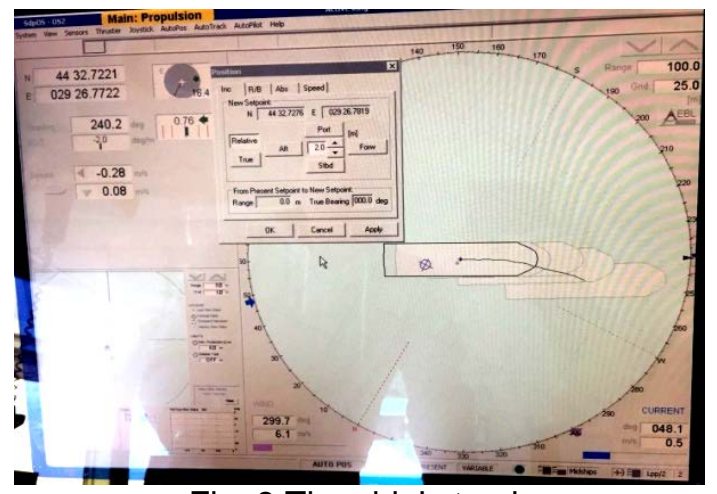

Fig. 8 The ship's track

When the vessel reaches the final position, all data from sensors and reference systems information are calculated, and resultant force is counteracted by the system for keeping the vessel in position (Fig. 9).

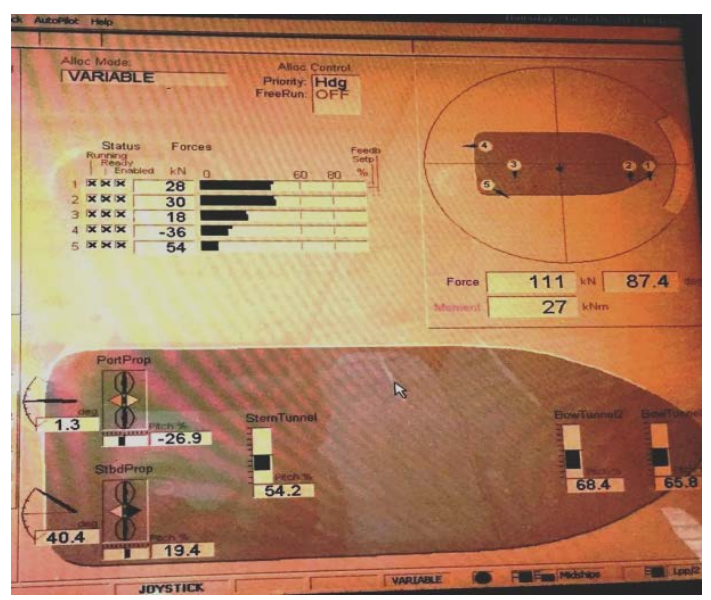

Fig. 9 The system counteracting
In Auto Position mode the Dp operator adjusts the ship's heading in such way that loading of thrusters to be as minimum as possible and the vessel position deviation to be in the settled limits. So the DP operator will choose the ship's allure related to environmental acting forces and he will achieve the best ratio of operating positioning, power consumption and thruster solicitation (Fig. 10).

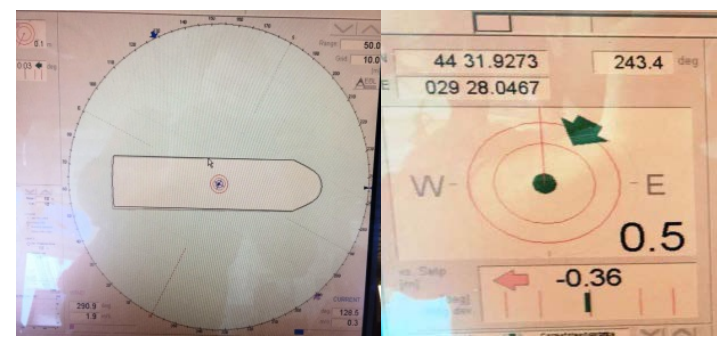

Fig. 10 The adjusting ship's heading in Auto Position mode

In this case, we can easily see that for a $1.9 \mathrm{~m} / \mathrm{s}$ wind speed from $290.9^{\circ}$ and $0.3 \mathrm{~m} / \mathrm{s}$ current velocity from $128.5^{\circ}$, the thrusters loading response is minimum, as it shows in figure 11 , and vessel keep's the position with maximum efficiency (Fig. 11).

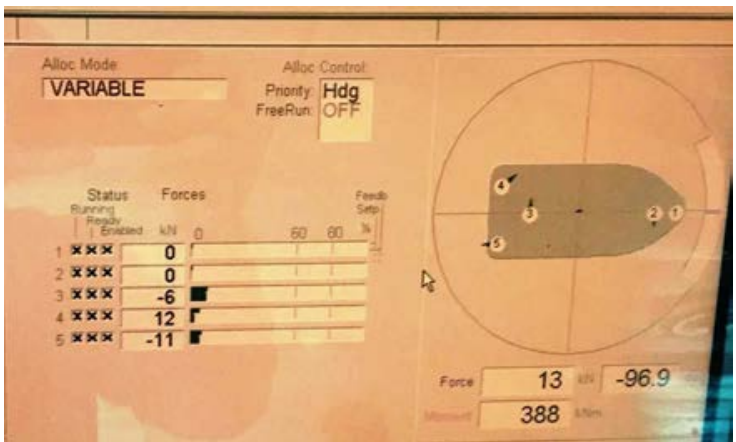

Fig. 11 The Thrusters loading response

\title{
Conclusions
}

The $\mathrm{Dp}$ system is used for a wide range of activities involving keeping the fixed position, precise maneuverability, the track and other specialist positioning abilities.

After the implementation of this technologyin orderto have stable, efficient and safe extraction of oiland gas from the sea bed, stationary positioning of the drilling, crane vessels, shuttle tanker, dredging, rock dumping vessels or pipe-lay vessel, even for port maneuvering, there has been large reduction in number ofaccidents and efficiency of extraction has also increased. 
"Mircea cel Batran" Naval Academy Scientific Bulletin, Volume XX - 2017 - Issue 1 The journal is indexed in: PROQUEST / DOAJ / Crossref / EBSCOhost / INDEX COPERNICUS I DRJI / OAJI I JOURNAL INDEX I I2OR / SCIENCE LIBRARY INDEX / Google Scholar / Academic Keys/ ROAD Open Access I Academic Resources / Scientific Indexing Services / SCIPIO / JIFACTOR

Dynamic positioning concerns directly the automatic control of sway, surge, and yaw. Longitudinal and translation movement are strictly related to the vessel position, while yaw is related to vessel orientation (heading). These movements are controlled by the operator who makes the set points for position and heading.

The Dp operator will choose the ship's allure related to environmental acting forces, and he will achieve the best ratio of operating positioning, power consumption and thruster solicitation.

\section{Bibliography}

[1] Iorgulescu D., Samoilescu Gh., Toma A, Atodiresei D., Sisteme de propulsie electrica in transportul naval,Buletinul AGIR, Supliment nr.3,An 2016, ISSN-L 1224-7928, Online: ISSN 2247-3548

[2] IMCA 1998-2012: „Introduction to Dynamic Positioning“ , http://www.imcaint.

com/divisions/marine/reference/intro.html

[3] Katona C., Toma A., Navigation equipment integration in the simplified voyage data recorder JRC JCY1850, "Mircea cel Batran" Naval Academy Scientific Bulletin, Volume XVII, 2014

[4] Nitilaksh Desai, Dynamic Positioning: Method for Disaster Prevention and Risk Management, Procedia Earth and Planetary Science 11 ( 2015 ) 216 - 223

[5] „Dynamic positioning - basic principles“, http://www.km.kongsberg.com/ 